\title{
Soil-Ecological Conditions Of The Kokand Oasis And Issues Of Recultivating Them
}

\author{
Mirzahmedov Ismoiljon Karimjon ugli \\ Professor, \\ Geography department, \\ Namangan State University \\ Namangan, Uzbekistan
}

\section{G OPEN ACCESS}

The American Journal of Agriculture and Biomedical Engineering JULY 2020

Page No.: 35-42

Volume-II Issue-VII

PUBLISHED: 30 JULY 2020

www.usajournalshub.com/inde x.php/tajabe

Copyright: Original content from this work may be used under the terms of the Creative Commons Attribution 4.0 licence.

Abstract: This article describes the environmental conditions of the soils of the Kokand oasis and the issues of their recultivation, the changes that are taking place and the impact of erosion processes on soil fertility, as well as measures to combat them.

Keywords: Oasis soils, recultivation, erosion processes, soil fertility, chemical polymers, soil salinity, amount of precipitation, deflation, environmental problems, anthropogen factors.

\section{Introduction}

The territory of the Republic of Uzbekistan is full with unique irrigated agricultural regions. For this reason, the reclamation here has been paid special attention since ancient times. After gaining independence, our republic always takes care of the effective use of irrigated lands, increasing the productivity of soil and the yield of agricultural crops. 
As indicated in the decree of the president of the Republic of Uzbekistan "on measures for effective use of land and water resources in agriculture"in June 17, 2019, PF - 5742, at the present time, more than 20 million hectares of land, including 3.2 million hectares of irrigated land, are being used to produce food for the needs of the population and to provide the economical system with products.

Large-scale irrigation and melioration activities are carried out within the framework of state programs in order to effectively use soils in our country, increase the fertility, improve the reclamation status and water supply.

The main texture and properties of soils in our republic according to the types of zone, the humus state and its components, the soils exposed to erosion of oases are practically unexplored. And this is due to research from soil specialists on hungry and brown soils, meadow and swamp - oasis soils, fertile soils, oasis cultural soils, the main properties and problems of their conservation and restoration. Also, the clay soils developed on the tertiary period deposits are slightly saline, on which the water is considered to be moderately mineralized to a depth of $5-10 \mathrm{~m}$. But it should be noted that in the irrigated soils of oasis, the levels of water are around $3-5 \mathrm{~m}$, mineralized at different levels, they are directly involved in the re-salinity of soils [4].

The accumulation of salts and salinity of the lands occurred in the steppe region and the region of soils, that is, in the regions of the Republic of Karakalpakstan, Khorezm, Bukhara, Sirdarya, in the regions of Kashkadarya, Surkhandarya, Navoi, Samarkand, Fergana Valley. If compared to the dynamics of the rate of salinity in 2000-2010 years, we can see that salinity reached 2446,9 , that is, 65,9 percent in the Republic.

Purposes and objectives of the study: The study of the impact of erosion processes on soil-environmental conditions and productivity in Kokand oasis and the study

of effective advanced experience in this regard was defined as the objective of the study. The study of soil-ecological conditions of the Kokand oasis, the discovery of natural and anthropogenic processes affecting soil fertility, as well as the analysis of soil-environmental problems is one of the main tasks of the research work.

\section{The Main Part}

The history of irrigation of the Kokand Oasis has a long period, as a result of this 
process, significant changes occurred in the soil cover, the process of soil formation has passed from the automatic mode to the side of half-gomorph soil formation. According to him, the soils of the Oasis are characterized by a specific morpholitogenetic structure, agrochemical, agrophysical and meliorative texture and properties. In the greater part of the oasis, the annual amount of precipitation is less than iother regions of the Fergana Valley $80-100 \mathrm{~mm}$, around the city of Kokand $98 \mathrm{~mm}$. The relative humidity is much lower, the temperature is relatively hot and dry, and the air pressure decreases as a result of warming up the temperature in spring and autumn.

At the same time of the year, through the Khujand gate, the Kokand wind blows from Mirzachul to the valley, the speed of the wind reaches $20-25 \mathrm{~m} \backslash \mathrm{sec}$. Thus, wind erosion in the Kokand Oasis is strongly developed. Because this type of erosion occurs in a dry climate, where the annual amount of precipitation is low, the air temperature of spring and summer months with high humidity evaporation from the Earth is hot, under conditions with low relative humidity [2].

Today, it is possible to observe the formation of new small - scale sand masses as a result of the blowing and scattering of the sand "Kokand wind" in the Besharik, Furqat, Uzbekistan, Dangara, Uchkoprik, Buvayda, Baghdad districts located in the Kokand Oasis. Because the sands in this area are located in the direction of the wind, about 100 tons of sand is blown from each hectare of land throughout the year. As a result, the barkhans formed in the central Fergana desert can Silge up to 14 - 20 meters per year [3].

As a result of the many years of scientific research conducted by soil-erosion scientists K.Mirzajonov, M Hamrayev, it became clear that fertile soils, cultured in very large areas in the Kokand Oasis, were left under sandy barkhans due to wind erosion. According to their account, it is established that in the oasis there are such lands about 10 thousand hectares. The composition of these soils includes 2 - 3 percent soil and water - resistant grainstructure up to 40-50 percent, from the slopes of the earth $50-70-100$ buried with sand at a depth of CM. If a layer of these soils is rolled out on the plantation plug, the soil becomes wind-resistant and fertile soil. Especially it is recommended to conduct these activities in the autumn.

In the large area of the Kokand oasis are composed of hungry and brown soils, as well as 
sandy desert soils fortified with shrubs, such soils occupy large areas on the territory of the above-named districts.

The mechanical composition of both these two soil types is water-permeable, so that water does not accumulate on the surface part of the Earth, and washing is rather sluggish. Another reason for not washingit is that the relief is flat. But the wind can easily dust and scatter these soils. The deflation of the cocaine wind in the regions where the same soils are distributed is clearly visible. Organized to prevent wind erosion, a sharp reduction in the area of tree-growing paves provide a wide way for the development of erosion. The risk of erosion increases as a result of irregular cutting of shrubs in ihotazars established with the aim of strengtheningsands, their area decreases year by year [5].

Several newly mastered (mechanical composition is light) lands of the western and central part of the oasis suffer from wind erosion. Now, as a result of improper irrigation and farming in these lands, many areas are turning into abandoned lands, ravines, leaving the agricultural fund. According to the data provided, 20 percent of the total area of grasses soil is water erosion. Water erosion on 1430 thousand hectares of land in the territory of Uzbekistan, land erosion on 750 thousand hectares of land in lalmi, deflation on more than 2 million hectares of land in three regions. In particular, 500 thousand hectares of Fergana Valley were subjected to soil erosion, according to which 160 thousand hectares of irrigated land, 40 thousand hectares of land and 80 thousand hectares of land subject to cliff erosion, deflation was determined to be 90 thousand hectares. According to this, as a result of insufficient implementation of measures on the extensive use of organic fertilizers by users of agricultural lands in our country, the amount of humus in irrigated soils has decreased by $10-15$ percent in the last 30 years, as a result of which the irrigated land, rich in the equivalent account, exceeds 450 thousand hectares.

In the Fergana Valley, issues such as soil erosion, its causative factors, especially anthropogenic factor, the degree of resistance to irrigated soils and their erosion types, the risk of erosion in the effective use of irrigated lands, the increasing incidence of erosion have not yet been studied sufficiently from a practical point of view. In places adjacent to the Central Fergana steppes of the Kokand oasis, the area of various plants planted with the aim of reducing the wind speed is also almost disappearing. The composition of the 
lands used in agriculture in the districts located in the oasis is reflected in Table 1 below.

\section{Table 1.}

The lands of Kokand oasis used in agriculture

\begin{tabular}{|c|c|c|c|c|c|c|}
\hline \multirow[b]{2}{*}{$\begin{array}{l}\text { Names of } \\
\text { districts }\end{array}$} & \multirow{2}{*}{$\begin{array}{l}\text { Territory } \\
\text { in } \\
\text { thousan } \\
\text { dhectare } \\
\text { s }\end{array}$} & \multirow{2}{*}{$\begin{array}{l}\text { The land } \\
\text { used in } \\
\text { agriculture, } \\
\text { thousand } \\
\text { hectares }\end{array}$} & \multirow{2}{*}{$\begin{array}{l}\text { In addition, } \\
\text { irrigated } \\
\text { fields,thou } \\
\text { sand } \\
\text { hectares }\end{array}$} & \multicolumn{3}{|c|}{$\begin{array}{l}\text { Compared to the land } \\
\text { used in agriculture, in } \\
\text { percent }\end{array}$} \\
\hline & & & & $\begin{array}{l}\text { Irrig } \\
\text { ated } \\
\text { land }\end{array}$ & $\begin{array}{l}\text { Perennial } \\
\text { plantatio } \\
\text { ns }\end{array}$ & $\begin{array}{l}\text { Pastu } \\
\text { res } \\
\text { and } \\
\text { fields }\end{array}$ \\
\hline Besharik & 77.4 & 27.5 & 25.2 & 75.9 & 13 & 11.1 \\
\hline Baghdad & 33.3 & 22.7 & 20.7 & 76.9 & 13.9 & 9.2 \\
\hline Buvayda & 27.9 & 18.1 & 16.9 & 88.0 & 5.2 & 6.8 \\
\hline Dangara & 43.5 & 20.8 & 19.1 & 87.6 & 4.2 & 8.2 \\
\hline Uchkuprik & 27.5 & 18.9 & 17.0 & 80.9 & 8.8 & 10.3 \\
\hline Furkat & 30.5 & 16.5 & 15.2 & 90.3 & 1.6 & 8.1 \\
\hline Uzbekistan & 68.8 & 23.4 & 21.6 & 60.6 & 26.6 & 12.8 \\
\hline
\end{tabular}

The table was compiled by the author using the data of the Fergana regional statistical department.

As it can be seen from the table, it is possible to see that the area of perennial plantations is more suitable for the regions of Uzbekistan, Baghdad and Besharik than in comparison, but the area of hay and bows is slightly less occupied. Also, the main part of the perennial plantations, which occupy a large area in the above districts, coincides with the contribution of gardens in the southern regions of the Kokand oasis. At the same time, when mulberry and willow plant species are planted in order to reduce the speed of winds around cultivated fields, protect the soil from erosion, the area of these plantations is almost disappearing.

Wind erosion, which occurs in the fields of cultivation of agricultural crops of districts located in the Kokand oasis, is considered one of the unpleasant environmental problems. 
And measures aimed at preventing such processes are carried out very quietly, or pre existing plantations, while the area of extinction is reduced from year to year, while in some areas it is completely lost. The reasons for the origin of such a condition can be directly related to the increase in the number of inhabitants in the oasis from year to year (Table 2).

\section{Table 2.}

The growth rate of the population of the Kokand oasis in 1989-2019 years

\begin{tabular}{|l|l|l|l|l|l|}
\hline \multirow{2}{*}{$\begin{array}{l}\text { Names of of } \\
\text { districts }\end{array}$} & Year $\begin{array}{l}\text { The amount of people, in thousands } \\
\text { establish } \\
\text { ment }\end{array}$ & $\begin{array}{l}\mathbf{1 9 8 9}^{\text {th }} \\
\text { year }\end{array}$ & $\begin{array}{l}\mathbf{2 0 1 0}^{\text {th }} \\
\text { year }\end{array}$ & $\begin{array}{l}\mathbf{2 0 1 6}^{\text {th }} \\
\text { year }\end{array}$ & $\begin{array}{l}\mathbf{2 0 1 9}^{\text {th }} \\
\text { year }\end{array}$ \\
\hline Besharik & 29.09 .1926 & 140.9 & 181.2 & 208.1 & 224.6 \\
\hline Baghdad & 31.12 .1964 & 108.0 & 174.8 & 193.3 & 210.4 \\
\hline Buvayda & 26.12 .1973 & 111.2 & 178.9 & 206.4 & 222.2 \\
\hline Dangara & 07.12 .1970 & 87.3 & 144.1 & 158.0 & 170.1 \\
\hline Uchkuprik & 29.09 .1926 & 113.9 & 183.3 & 206.6 & 224.4 \\
\hline Furkat & 09.04 .1992 & - & 97.1 & 107.6 & 115.8 \\
\hline Uzbekistan & 17.04 .1963 & 142.6 & 194.5 & 217.3 & 234.3 \\
\hline
\end{tabular}

The table was compiled by the author using the data of the Fergana regional statistical department.

It is known that the Fergana Valley is one of the most densely populated regions of our republic. In the Namangan region, an average of $1 \mathrm{~km}$.address in the Andijan region, if the location corresponds to 460-490 people, then this figure corresponds to 560-610 people. If the per capita ratio of irrigated lands in the Republic is 0.17 , then in the Namangan region this ratio will be $0.7-0.8$. As can be seen from the table, it is possible to see that the Kokand Oasis is distinguished from other oases of the Fergana Valley even by its territory, where the fastest population increase is observed. Farmers work in the irrigated land. In the meadow, the pet feeds, the land is used for their own purposes. As a result, the lithologicalgeomorphological, mechanical composition of the soil, water and air regime, physical, agrochemical and chemical-biological properties of the arable lands also changed [1]. 
ISSN (e): 2689-1018

In accordance with the purpose of systematic work on increasing soil fertility by users of all agricultural lands of the Kokand oasis, in particular, the development of complex measures for the widespread use of organic fertilizers, as well as identification, evaluation, monitoring of soil degradation and elimination of negative consequences, it is desirable to establish a system of measures to improve soil fertility. According to him, in order to prevent such unpleasant environmental conditions in the Kokand Oasis, it is necessary to carry out a number of regulatory measures, including:

- To prevent wind erosion, the width of the fields is 150 - 200 meters, consisting of Willow, poplar, birch, mulberry and fruit trees in the last row of the belt of trees;

- establishment of aquatic forests in the areas where the newly mastered part of deserts and wind erosion is observed;

- application of organic and mineral fertilizers and improvement of land techniques in the method of stratification in the areas where erosion-affected soils are spread;

- Development and implementation of the instruction on determination of soil and groundwater composition of Kokand Oasis;

- Allocation of subsidies for the improvement and effective use of land reclamation and environmental conditions in the Kokand Oasis;

- reconsider the characteristics of the location of agricultural crops, adapt to soil types and give a wide place in it to the fruit and vegetable sectors;

- application of substances such as chemical polymers nerozin, lateris in order to protect soils from wind erosion;

- to protect the cover of soils, sticky grasses are like planting grass, for example, which will be divorced and other fodder.

It is also necessary to enrich the world of plants characteristic of the steppe region in undigested parts of the Central Ferghana, that is, to multiply the white saxaul, black saxaul, cherkess, kandym, yantak kablar, which grows naturally. These measures serve to strengthen the sands, to prevent migration to the oasis, as well as preventing wind erosion.

The influence of wind erosion on salinity and desertification of soils of the Kokand Oasis is incomparably greater. Therefore, it is necessary to seriously study the ways of salinity of oasis soils and the development of measures against it in order to meet the needs 
of the population, to rival the industrial and agricultural sectors.

\section{Conclusion}

If the above requirements are taken into account, the increase in soil fertility and more effective use will be achieved. In addition, this form of protection of soil-ecological conditions provides an opportunity for conducting joint research, use in agriculture and other sectors, as well as settlement of oasis regions. If soil-ecological conditions of the Kokand Oasis are prevented, the impact of natural and anthropogenic processes on its productivity, agricultural sectors will develop and high economic efficiency will be achieved.

\section{References:}

1. Decree of the president of the Republic of Uzbekistan on measures to ensure more effective organization of the process of acquisition of rights over land parcels and other immovable property as part of the South Caucasus pipeline expansion project more https://lex.uz/docs/4378526

2. Baymirzaev K.M., Mirzahmedov I.K. Terrestrial waters of the oases of the Fergana Valley and their geological features // information of the Society of geography of Uzbekistan. 46volume. - Tashkent, 2019. - B44-47.

3. Baymirzaev K.M. Soliev I.R, Mirzahmedov I.K. Environmental optimization of Kokand Oasis landscapes. - N:" Namangan " publishing house. 2019. - It's 110b.

4. Mirzahmedov I.K. The importance of the development of Fergane oasis / / Science and Earth. №1. Nauchniy magazine. Khujand, 2020. - b32-36.

5. Morgan R. Soil 